\title{
TRADITIONAL CRAFT SKILLS IN THE CONTEMPORARY LATVIAN RURAL ENVIRONMENT ${ }^{1}$
}

\author{
ANETE KARLSONE \\ Institute of Latvian History \\ University of Latvia \\ LV-1050 Rīga, Kalpaka bulvāris 4 \\ anete.karlsone@gmail.com
}

DDOI: $10.17234 /$ SEC.28.4

Review article

Received: 13. 4. 2016.

Accepted: 13. 6. 2016.

This article is an open access article distributed under the terms and conditions of the CC BY-NCND 4.0 license.

This article intends to give an insight into what place the traditional craft skills occupy in the contemporary Latvian rural environment, using as a point of observation the activities of the 'Meet your Master!' event, organised by the Latvian National Centre for Culture. The interest of both the society and the individuals in focusing on the traditional cultural heritage is encouraged by the desire for expressing their cultural identity in today's cosmopolitan world. The same motivation prompts the use of traditional knowledge in rural tourism, in the activities of individual manufacturers etc. Traditional skills are the basis for mutual interaction among the community members and a meaningful way of spending leisure time, which as a whole lead to improving the quality of life.

Keywords: intangible cultural heritage, traditional skills, sustainable rural development, ethnology

\section{INTRODUCTION}

Nowadays, with the increasing concentration of population in cities, the topic of the further harmonious and sustainable rural environment development is increasingly becoming a crucial issue. At present, sustainable development is discussed a lot and in different contexts. Quite often the concept of sustainability is understood as technologies and the use of resources. However, it should not be associated only with

\footnotetext{
${ }^{1}$ The study of the Latvian traditional craft skills is part of the Latvian National Research Programme 'Letonica: Research on History, Language and Culture' project 'Latvian history: cultural environment and socio-political developments in the context of the Baltic Sea Region.'
} 
modern technologies and the green lifestyle. More importantly, in terms of maintaining and developing the living environment, it provides opportunities for both employment and leisure. The intangible cultural heritage can also be used to facilitate better quality of life. The ways in which tangible and intangible cultural heritage can be used to ensure sustainable development were discussed at the UNESCO conference in Bergen (Norway) in March $2014 .^{2}$ The definition of the concept 'intangible cultural heritage' adopted by the UNESCO encompasses a rather wide variety of cultural phenomena, including traditional craft skills:

1. The 'intangible cultural heritage' means the practices, representations, expressions, knowledge, skills - as well as the instruments, objects, artefacts and cultural spaces associated therewith - that communities, groups and, in some cases, individuals recognize as part of their cultural heritage. This intangible cultural heritage, transmitted from generation to generation, is constantly recreated by communities and groups in response to their environment, their interaction with nature and their history, and provides them with a sense of identity and continuity, thus promoting respect for cultural diversity and human creativity. (..)

2. The 'intangible cultural heritage', as defined in paragraph 1 above, is manifested inter alia in the following domains:

(a) Oral traditions and expressions, including language as a vehicle of the intangible cultural heritage

(b) Performing arts

(c) Social practices, rituals and festive events

(d) Knowledge and practices concerning nature and the universe

(e) Traditional craftsmanship (UNESCO's Definition).

In turn, the ethnologist Barbara Kirshenblatt-Gimblett indicates a close link in the cultural heritage between the world of things and the manmade environment:

The continuity of intangible heritage would require attention not just to artefacts, but above all to persons, as well as to their entire

${ }^{2}$ Source: http://whc.unesco.org/en/events/1124 
habitus and habitat, understood as their life space and social world. (Kirshenblatt-Gimblett 2004:54)

The village is a favourable environment for practising the traditional craft skills, as earlier many of them in the territory of Latvia formed a constituent part of the peasants' way of life. Similar to the processes in other parts of Europe, formation of the folk culture took place in the period of the feudal class system, when the main role in the formation of the regional characteristics was played by the rural people (Köstlin 1997:106-115). It could be one of the prerequisites for the traditional skills to be inherited particularly in the rural environment. However, this is not always the case. Lifestyle has changed not only in cities but also in rural areas. Therefore, it often happens that in rural areas traditional craft skills are acquired anew, renewed. In this context, engagement in traditional craft skills could be considered creation or invention of tradition. Or as pointed out by K. Köstlin: “One should accept 'invention' as a legitimate practice and as an act of creative consumerism" (Köstlin 1999: 292). Nowadays, the growing interest in the traditional knowledge is partly a spontaneous protest against the general globalisation of different aspects of life. This is related to the concepts and views of the modern lifestyle as constant acceleration, in contrast to the earlier steadiness and peace (Ibid. 289-290). Nevertheless, "ethnographic knowledge will be recognized for what it has always been: a contribution to the production of cultural commodities." (Ibid. 293). In our time, the growing interest in traditional culture to an extent corresponds with the processes that took place in the 1920s, when practicing of the traditional culture was closely connected with the realisation of feelings of being natural and those of national identity (Tschofen 1999:237-238). In view of the modern processes the ideas of K. Köstlin appear completely agreeable: "If we assume that time, locality, culture, and ethnicity are the decisive discourses of modernity, if these are the parameters at whose edges the present continually generates itself, then memory is central." (Köstlin 1999:294). Therefore, studying the cultural heritage anew is the process of creating a close connection between the present and the past.

A new re-actualisation of traditional knowledge in the Latvian society is not only associated with the people's self-initiative but is also 
encouraged by the events hosted by the state and public organisations. One of them, which has been taking place in Latvia every spring since 2009, is the 'Meet your Master!' event offering a set of separate workshops: The information website of the Latvian National Centre for Culture (LNCC) ${ }^{3}$ reads as follows:

In recent years, the 'Meet your Master!' event in Latvia has been attended by 18,000 people of different generations, and every spring it is an event, which members of various age and social groups are looking forward to - families, people with previous knowledge and those who have only now decided to learn something new in order to improve themselves and their skills. The intention of the event is to acquaint a wider public with the craftsman, with their knowledge and skills that have been preserved and handed from generation to generation. The form of the event is free, Masters organise workshops, individual lessons, open workshops, demonstrations, lectures, readings, concerts or dancing, etc. ${ }^{4}$

Up to now, in specialist publications, the Latvian traditional crafts have been viewed mainly as a branch of contemporary applied arts (Čakša 2009; Jansone 2008a; 2008b; Karlsone 2014; Ziṇgîte 2008). This article is to give an insight into what the place of traditional craft skills in the contemporary Latvian rural environment is, using as a point of observation the activities of the 'Meet your Master!' event organised by the Latvian National Centre for Culture. Within the scope of this article attention will be paid mainly to the positive aspects of what traditional skills are able to give for sustainable rural development. The study aims to:

Clarify the topical issues and nature of traditional activities in the rural environment

Find out which areas of traditional crafts are the most popular(attracting the greatest interest) in today's society

Outline the use of traditional craft skills for sustainable rural development.

\footnotetext{
${ }^{3}$ Source: www.satiecsavumeistaru.lv

${ }^{4}$ Source: http://www.satiecsavumeistaru.lv/par/
} 


\section{SOURCES OF THE STUDY}

As sources of information in the study the unpublished materials of the Latvian National Centre for Culture have been used: application forms filled in by the craftsmen in order to participate in the 'Meet your Master!' and the reports about the course of the event. Application forms are the largest part of the materials. In order to participate in the traditional knowledge event 'Meet your Master!' the applicant has to submit an application in a particular form to the Latvian National Centre for Culture. Photos illustrating the respective traditional skill can supplement it. The form must provide information about the participant: name, surname and contact information (address, etc.); description of the activity: its characteristics and their motivation to participate in the event, Master and the skill they will present, content of the activity planned and the venue etc. The submitted application forms are evaluated by the experts of the Latvian National Centre for Culture who assess the quality of the activity proposed and its compliance with the nature of the event. After evaluation, the activity is either included in the common list of activities, which is published later on, or rejected.

After the completion of the 'Meet your Master!' event, the organisers of the workshops submit reports on the course of the activity. In addition to contact information, it provides the following information: course of the event, its brief description, mentioning the number of participants, and answers to the following questions: What should be improved organising the event next time? What activities do you see as a continuation of the event in your municipality in future? What successful partnerships and new initiatives have begun in the framework of the event? By comparing the reports with the applications, it can be concluded that not all the workshop organisers submit the reporting forms.

In addition to the above mentioned documents, records of structured interviews have been used, which, were conducted during the event in 2010 by the students of ethnomusicology programme of Jāzeps Vìtols Latvian Academy of Music in conversations with the workshop organisers. Similarly, the information found on the Internet has also been used in the study: informative reports and reports on the course of the event. Document studies are supplemented with information obtained from the interviews 
conducted by the author of the article during the 'Meet your Master!' event in 2015 in a number of rural areas and the incorporated (participatory) observations living in the rural environment of Latvia for a long time.

Analysing the application forms for the participation in the event and reports on its progress submitted to the Latvian National Centre for Culture by the craftsmen, statistical material on the topics of individual workshops and their territorial distribution can be obtained, as well as the information about the forms of learning the craft, motivation to participate in the event (which is often stated formally) and other information. However, the interviews with the participants carried out during the event together with the information given in the application forms provide an insight into the real motivation for practising traditional craft skills.

\section{'MEET YOUR MASTER!'}

There are various sources where one can read about the beginnings of the 'Meet your Master!' project in 2009 and its further development. However, the information in their most concentrated form are those prepared by the Centre for Culture Education and Intangible Heritage (now the Latvian National Centre for Culture) and can be found on the Latvian Association of National Cultural Societies website:

In autumn of 2009 the organisation of 'Traditional Skills Schools' began. The idea was to hold workshops over four weekends (Saturdays) simultaneously in different places of Latvia, where it would be possible to acquire ancient craft skills under the guidance of Masters. The project was continued with great success in spring of 2010 - in Zemgale and Sêlija [ethnographic regions of the southern part of Latvia - A.K.] in autumn of 2010 - in Vidzeme [ethnographic region of the centre of Latvia - A.K.] and in spring of 2011 - in Latgale [ethnographic region of the eastern part of Latvia - A.K.]. During the 'Meet your Master!' event to take place on 30 - 31 March, and on 1 April 2012 in the Latvian regions, we propose to organise open workshops, individual lessons, model lessons, demonstrations and concerts, public discussions and debates (Bika 2012).

Initially, the organisers (LNCC) carried out a rigorous selection of the traditional skills Masters, as the demonstration of traditional skills was to 
be remunerated, and the total budget was limited. Workshop leaders were chosen from different places of Latvia (mostly from rural areas). In 2010, they were interviewed (surveyed) and the event was documented by the students of ethnomusicology programme of Jāzeps Vītols Latvian Academy of Music.

From 2012 onwards, a wider circle of craftsmen and bearers of other skills could participate in the Traditional skills schools, since, due to the economic situation at the time, it was not possible to pay compensation for the demonstrations. On the one hand, the Masters had lost their direct material interest in sharing their knowledge, but on the other, it made the event more democratic given that more people, who were interested, could apply to participate in it. The submitted applications were evaluated, but the selection criteria were not very strict any more. Since there was a substantial increase in the number of places for demonstrating traditional skills, there was a lot of interest among the bearers of these skills. Initially in 2009, Traditional skills schools were organised in 11 places in Latvia within the 'Meet your Master!' event. However, in 2012 they were available in as many as 109 places (LNCC materials). Also, the Latvian society welcomed this event with great enthusiasm and the number of interested parties grew rapidly. Every year more and more Masters and visitors took part in it. Overall, until 2016, as already mentioned above, it attracted the attention of more than 18,000 people. ${ }^{5}$

The event attracted a lot of publicity through the mass media (radio, $\mathrm{TV}$, Internet). Although no remuneration for organising the workshops was given, a part of the Masters used Traditional skills school to boost the interest of the public in their occupation. During the event, the annual 'Meet your Master!' map, which contains detailed information about the venue, time and theme of individual workshops, was also available on the Internet.

As the analysis of the applications showed, most activities (workshops, demonstrations of crafts, etc.) took place in rural environment, i.e. parish centres, villages, and towns. For example, in 2012 out of 109 places which applied, 93 were outside major Latvian towns, whereas in the spring of 2015 the same was true for 108 out of 176 activities.

\footnotetext{
${ }^{5}$ Source: http://www.satiecsavumeistaru.lv/par/
} 
Workshops are different in nature. At some of them one Master is demonstrating the craft skills, while at others a combination of several workshops is offered, where it is possible to visit different Masters at the same time or one after the other. The Traditional skills school framework also comprises folk group concerts, including the activities of the children and youth folk group festival 'Pulkā eimu, pulkā teku' (regional shows concerts).

According to the UNESCO definition, a very broad range of activities can be considered traditional skills nowadays. As was already mentioned, they comprise both the activities of artisan nature and storytelling, singing, playing music, dancing and other forms of inherited knowledge, such as traditional medicine, etc.

The thematic breakdown of the activities in the 'Meet your Master!' event is dominated by a variety of traditional craft skills.

Fields of activities

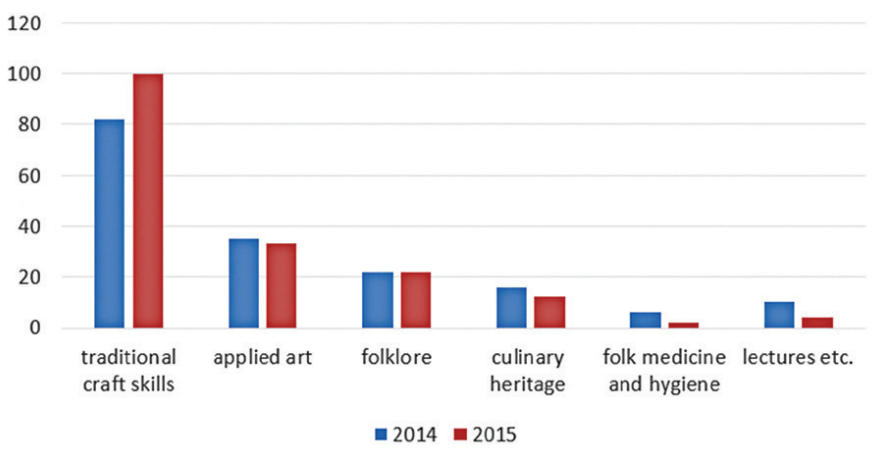

Picture 1: Fields of activities in the event 'Meet your Master!' (data of years 2014, 2015).

Here they are not set apart according to their level of professionalism. They can be both widely used in everyday life and specialised, their acquisition requires certain training, and they are transferable to the field of professional craftsmanship. Such skills as knitting socks or gloves, making food following traditional recipes, etc., could be assigned to the first group as they are still widely used in everyday life in many places of Latvia. The second group could comprise, for example, blacksmith's or potter's skills, etc. Both the first and the second group skills can be considered traditional. 
Craft skills, in contrast to the traditional knowledge in other areas, attract the greatest interest because they manifest people's willingness to engage in various kinds of handicrafts in order to express themselves practically and creatively. Among the different areas of crafts, there are lesser known and widespread ones. In this regard, the public interest is attracted by those activities which are no longer widespread today. Thus, participants of the event can learn something new and unknown until then. Nowadays, women's handicrafts, such as knitting, are still widely practised in Latvia. If a workshop offers a particular knitting technique inherited in the family, then it is easier for the participants with previous knowledge to perceive the specific new information in the demonstrated skill. In general, it can be concluded that women's handicrafts, especially knitting and weaving, prevail among the traditional craft workshops

The traditional craft workshops
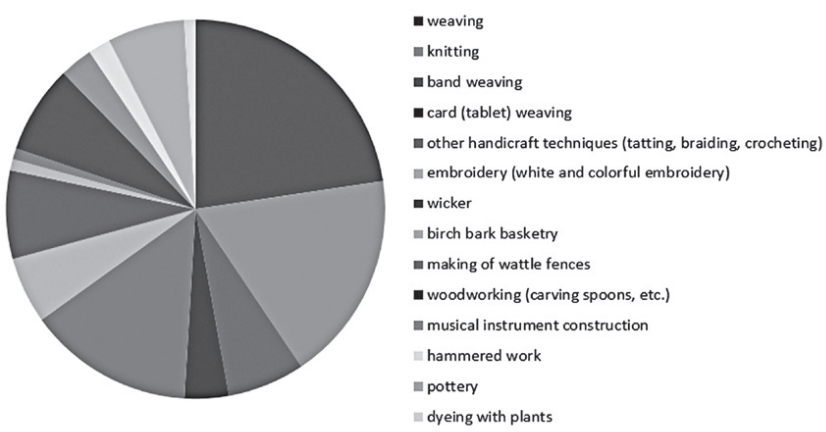

Picture 2: The traditional craft workshops in the event 'Meet your Master!' (2014)

Along with them, handicraft areas that could be attributed to contemporary applied arts (e.g. floristry, decoration) are often demonstrated and learned since their techniques are sometimes acquired from the Internet resources. Therefore, these skills, if actively taken over by the circle of the local community, can be regarded a part of intangible cultural heritage, because they, in accordance with the guidelines adopted by the UNESCO, are traditional and modern at the same time:

Traditional, contemporary and living at the same time: intangible cultural heritage does not only represent inherited traditions from 
the past but also contemporary rural and urban practices in which diverse cultural groups take part (UNESCO: Culture ICH).

Among the activities of various workshops within the 'Meet your Master!' those events that combine different traditional areas are gaining an ever increasing popularity, especially in rural areas: craft demonstrations are combined with the acquisition of culinary heritage and playing folk music, singing or story-telling.

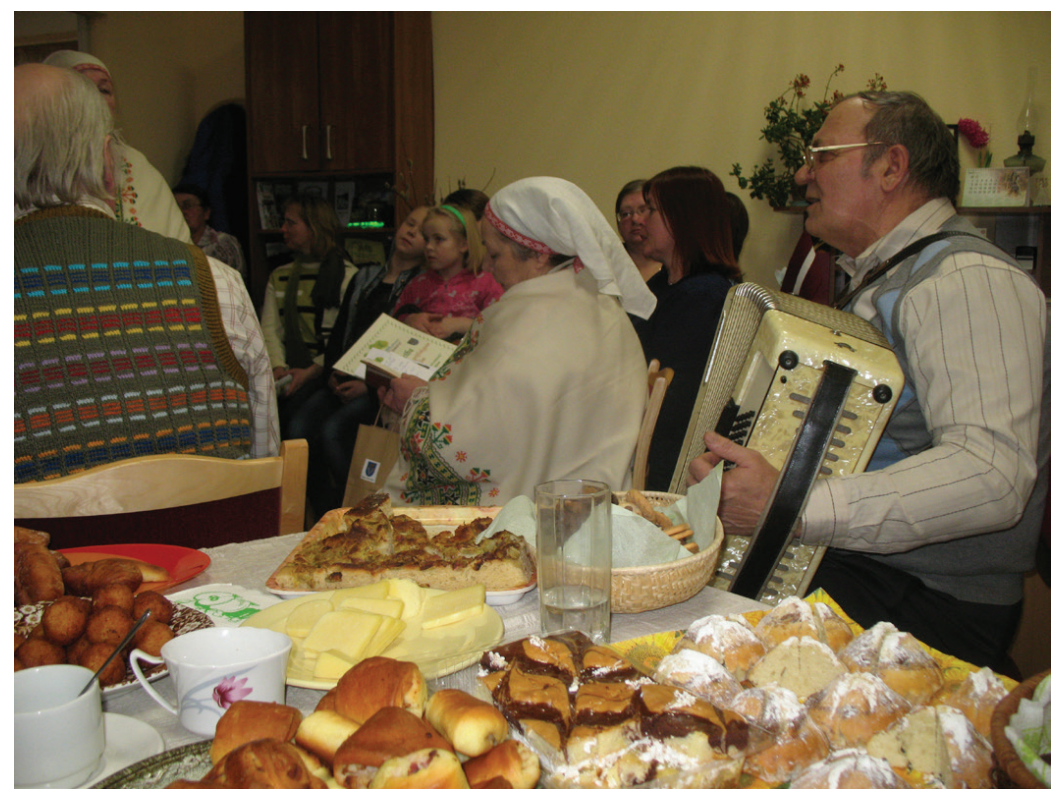

Picture 3: A workshop of 'Meet your Master!' which combine different traditional knowledge: craft demonstrations are combined with acquisition of the culinary heritage and playing folk music. Rugāji, 28 March, 2015

These events are perceived by both organisers and visitors as local community celebrations, in which people who have come from neighbouring or more distant surroundings also participate. Crafts workshops are interspersed by breaks with musical performances that take place after the food, which had been brought, is eaten. Most of the food is homemade, often following inherited recipes thereby fitting in with the area of traditional skills. Also, this category of events comprises folk group 
concerts, which are complemented by artisan demonstrations thus giving visitors an opportunity to try out a variety of different activities. Since in children's folk group concerts children and young people are both the participants and visitors, these events are used as a tool for active culture education.

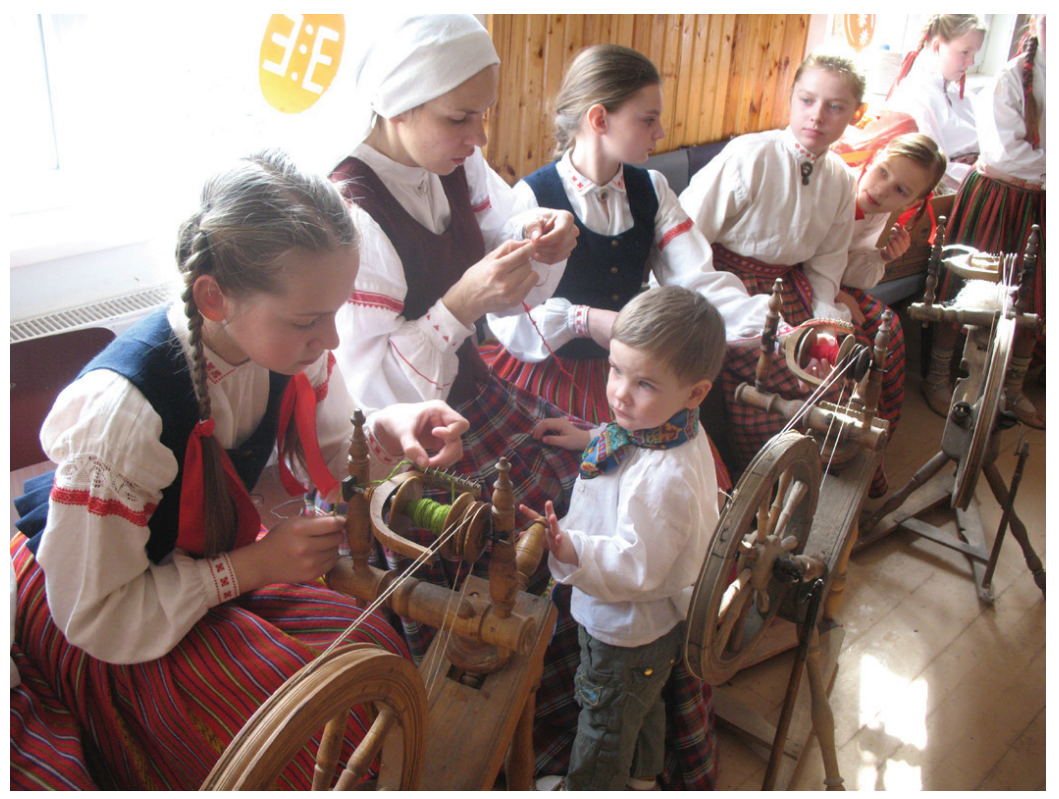

Picture 4: Girls from folklore groupe learn traditional women's work. Upite, 27 March, 2015.

Traditional skills, including the crafts, are used in the education of children and young people to actively promote local patriotism, and create and strengthen the feeling of having native roots. This fact is quite important in the context of sustainability, because a youngster with a strong sense of belonging to the local community may well link their economic activity directly with this environment in the future.

\section{DATA FROM THE INTERVIEWS}

The survey carried out in 2010 shows that quite often Master craftsmen have studied the technological bases in an applied arts school or in a handicraft group, but the production of traditional objects has been 
acquired through self-study from other craftsmen, specialised literature or other sources. Traditional culinary skills are acquired through direct inheritance. In this area it is very important not only to know something, but also to be able to do it. It means that the nuances of the process, which are not always possible to record in a written form (i.e., to read in written sources), are more important. All the Traditional skills school Masters surveyed in 2010 shared their skills outside the event, too. They taught the people interested both individually and in handicraft groups or an art school.

The interviews conducted by the author of the article in 2015, during the 'Meet your Master!' event, provide an insight into the society's viewpoints on the use of traditional knowledge in today's rural environment. In March 2015, within three days several workshops (the venues) were visited in the eastern regions of Latvia, on the territorial outskirts near the Russian border, as well as in the in the central part of the country. There are no large industrial enterprises in these places and they are 200 or more kilometres away from the capital (economic and political centre). In terms of economic development there are prospects for both rural tourism and small business development.

Male and female respondents from different generations were interviewed; nevertheless, the material should be regarded only as an illustration of the society's viewpoints. Since the time for the interviews was limited (only the day of the event), the data collected are not to be considered a quantitative and comprehensive material. Still, the observations carried out by the author of this article, who has been living in a rural environment for a long time, allow us to use the statements obtained in the interviews in a wider context. The opinions about the motivation to practice the ancient craft skills today, which were expressed in the interviews, provide a comprehensive and accurate description of the current situation in this area of the Latvian village.

By analysing the sources of information used in the study, it can be seen that in the majority of cases women are the inheritors, preservers, and further transmitters of traditional knowledge, including craft skills. Although among the traditional crafts demonstrated in 'Meet your Master!' there were carpenter's or cooper's craft, making of wooden plates and dishes, blacksmith's craft, minting of jewellery, wooden fence weaving and 
other traditional men's work, still women's activities prevail. These include all areas of women's handicrafts, as well as, in most cases, traditional cooking, folk medicine, etc. This shows that traditional craft skills as a way of ensuring the quality of life (which is an essential part of sustainable development), especially in rural areas, hold particular importance for women. Women in the Latvian village continue to be the main successors and preservers of traditional values. This is supported by the interviews conducted in 2015. The leader of Lizums artisans' group Lìga from Vidzeme [central Latvia] describes her own and other group members' focus on traditional crafts:

Together we are about 20 women. In 2004 there was a handicraft exhibition in Alūksne [administrative centre in the adjacent district] and I began to look for local people who are doing something. In 2008, for the Song Festival [Latvian Song and Dance Celebration] we already held our own exhibition in Gulbene [local regional centre]. The aim of the group is to inherit the ancient knowledge and to learn something new. If any of the artefacts are bought - very well, but this is not the main goal. [The most important is] the interest in our roots. The young ones come, too. We are learning at the meetings, also from the Internet. (Liga, Lizums, 29 March, 2015)

Folk group leader Daiga, a teacher from the neighbouring parish [Tilža], who is attending the event in Upite village (Latgale) [Eastern Latvia, near the Russian border] says:

"In the past weaving was set aside. Now people have been learning again, for the past 5 years. 'Meet your Master!' kindled this interest. People became unemployed - something needs to be done, then you think of anything. Crafts can be a private business. Baking bread, making smoked meat - in Balvi [regional centre] every month there are 'green' fairs. Also handicraft products have a good sale. In Tilža [neighbouring parish] there is a leisure club. Many women go there. Also the young ones join. If the mother weaves, then the daughter does, too. Those who stayed in the villages do." (Daiga, Upìte, 27 March, 2015) 
For example, in Rugāji village (Latgale) [Eastern Latvia] traditional skills make up the daily activities of the rural women's club on the one hand, and constitute the basis for cooperation between entrepreneurs and the local school in joint projects, on the other. Members of the rural women's organisation - society 'Ūdensroze' say:

"We had joint projects with the school and rural tourist organizations - workshops on the old crafts: cheese making, fish drying, weaving, furniture restoration, cake baking, woodwork - furniture, rocking chair making, candle pouring, soap making. [Handicraft group] we have been working for three years, our leader spent her childhood under the looms, but later did not know anything about all that. [Now] she is learning anew. Iveta Gabrāne from Baltinava [neighbouring parish] comes to teach us weaving. We are weaving national costume skirts, belts for the local dance group. We also make contemporary folk dresses." ('Ūdensroze' participants, Rugāji, 28 March, 2015)

This quote mentions an area of the use of traditional handicraft that is important for the upkeep of another tradition, which since 2008 has been inscribed on the UNESCO Representative List of the Intangible Cultural Heritage of Humanity (UNESCO, Baltic song and dance celebrations), and is vital for the Latvian cultural history namely, the Song and Dance Celebration tradition. In Latvia it also comprises making ethnographic national costumes and wearing them in song and dance festivals and related events. The making of the traditional national costume combines in itself various forms of handicrafts, which makes the work of many craftsmen necessary. The need to continue their production nowadays ensures the demand for the use and acquisition of these skills. In addition, it is also quite an important source of income for the craftsmen, as the purchase of traditional national costumes for dance groups and choirs, as well as for folk groups is financially supported by the local governments (attracting also the finances of various project funds).

Furthermore, men engage in traditional crafts in the Latvian village albeit in smaller numbers than women. Among them there are both older men, who learnt their craft from the craftsmen who were working in the first half of the 20th century, and young men, who have taken an interest in 
traditional crafts only now. The craft practised by men, such as cooper's craft (manufacturer of wooden planks) is often the one inherited from the grandfather or the father. In 2015, the men interviewed during the event 'Meet your Master!' in Latgale, Upīte village [Eastern Latvia, near the Russian border] talked about their motivation to take an interest in traditional craft skills and about whether these skills can prove to be useful in today's rural environment and how. Woodworking Master Andris, a young man, who demonstrated and taught wood turning with a foot-operated lathe, said:

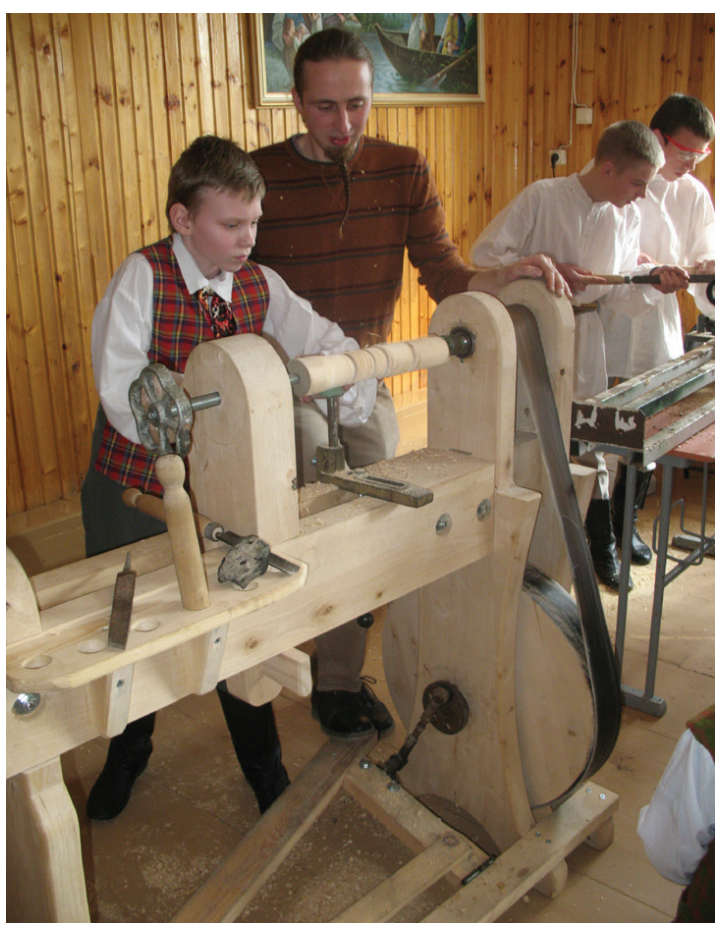

Picture 5: Workshop of woodworking with a footoperated lathe. Upìte, 27 March, 2015

"The traditional crafts are an alternative to passing the time in front of the TV, a way of self-improvement and tracing our own roots. Traditional craft skills can be used in the field of rural tourism, it gives me extra profit. [It is an] occupation, which provides for spending time at home, you do not have to look for work elsewhere." (Andris, Upīte, 27 March, 2015)

Traditional skills schools (demonstrations and workshops of ancient crafts) are often used to introduce children and young people to the cultural heritage of their nation. However, an interest in the traditional skills practised in the past encourages the people of mature age to also participate in the 'Meet your Master!' event. For example, a middle-aged man, a visitor of the event, a farmer from the neighbouring parish [Briežciems] Jānis whose motivation to attend the event is related to an interest in the crafts which were practiced by a close relative of his, says: 
"For someone [interest in the traditional] does not mean anything, while someone else is interested - it is deeply personal. I came to see how ropes are made. I tried it at home by myself, but it did not work. I want to learn the jobs my grandfather did." (Jānis, Upīte, 27 March, 2015)

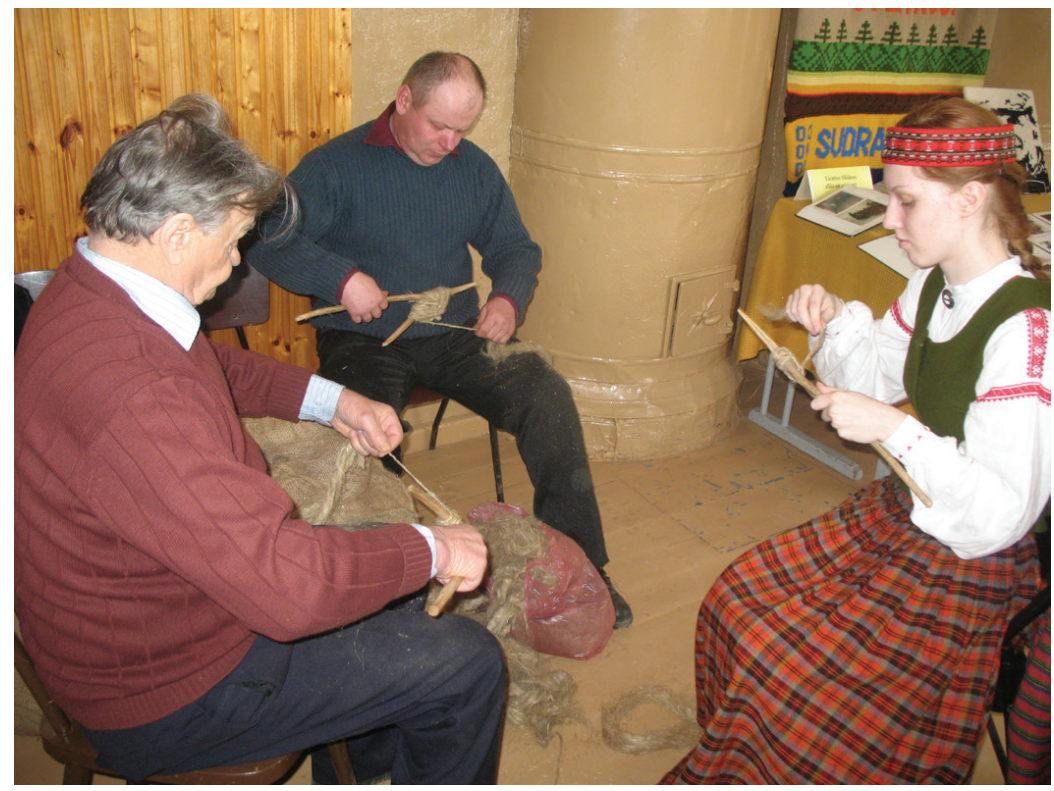

Picture 6: Workshop of making ropes. Upīte, 27 March, 2015

\section{CONCLUSION}

The interest in traditional craft skills in Latvian society is growing. This is due to personal initiative, and a desire to develop certain skills of individuals, a desire to explore their own traditional cultural heritage. It is also the result of public events (festivals, workshops, summer schools, etc.) organised by public institutions (e.g. the Latvian National Centre for Culture) and public organisations (various non-governmental organisations, groups of the like-minded).

In summarising the information obtained from the analysed materials, it can be concluded that traditional skills, including craft skills, in modern rural environment are used in several ways: 
Spending leisure time and socialising within the community: traditional skills are at the basis of interest groups' activities, i.e. women's clubs, handicraft groups, etc. Taking part in these activities is not only a meaningful way of using the leisure time, since one's creative abilities can become an essential part of their work, but also, more importantly, it is a way of socialising. In the course of daily life, it is important to meet the like-minded outside the household chores routine. This is particularly true when it comes to Latvian rural women's daily lives.

Traditional craft skills are an important resource for the activities of small businesses, including rural tourism. Within the framework of the 'Meet your Master!' event, representatives from this field took part as individual workshop leaders, as opposed to the demonstrations of a number of crafts together. Among the Masters of this group there were both women and men.

Traditional craft skills are used in the education of children and young people as well as in the lifelong learning projects. People get to know the cultural heritage both by learning certain handicraft skills (traditional craft skills) and by acquiring cultural history in general. This area contributes to the formation of local and ethnic identity. It is an important aspect in the context of sustainable development of the local community.

Traditional knowledge, including craft skills, as opposed to the acquisition of modern technology and other modern (new) knowledge, attracts the public attention for two main reasons:

They provide knowledge which links ethnic cultural heritage, and inheritance from previous generations with the local community. All of the mentioned aspects enable the sense of togetherness in the community to develop and strengthen, promote local and/or ethnic identity, which is becoming all the more relevant under the influence of globalisation processes;

Traditional craft skills are usually implemented with relatively simple tool, the key role is that of human capabilities. They show the diversity and strength of human creative spirit and skills. 
In conclusion, it should be stressed once again that the traditional skills have an essential, so far underestimated, role in the area of socialising in the local community. Traditional skills are the basis for mutual interaction among the community members and a meaningful way of spending leisure time, which as a whole provides for the improvement of the quality of life. Cultivation of traditional craft skills (acquisition, use) occupies quite a significant place among women's everyday life activities. This could be a separate research theme in the field of women's topics. Women's handicrafts represent the area of traditional skills that is most widespread among the activities of the 'Meet your Master!' event.

The interest of both the society and the individuals in focusing on the traditional cultural heritage is encouraged by the desire for expressing the cultural identity in today's cosmopolitan world. The same motivation prompts the use of traditional knowledge in rural tourism, in the activities of individual producers etc. It must be admitted, however, that the interest in traditional skills in various Latvian regions is varied and uneven. Nevertheless, the interest in the 'Meet your Master!' event is increasing year after year among both the Masters as well as the visitors, which suggests that the use of traditional skills could be a resource for further rural development.

\section{REFERENCES}

BIKA, Inga. 2012. "Satiec savu meistaru”. https://nkba.wordpress.com/2012/02/12/ satiec-savu-meistaru/ (accessed February 16, 2016).

ČAKŠA, Valda. 2009. "Latgalian traditional culture and regional identity: places of cultural memory and symbols". In Latgale as a Culture Borderzone, ed. Valentīna Liepa. Daugavpils: Saule, 116-130.

Field studies - interviews (2015) and observations (1992-2016) (from A. Karlsone personal archive)

JANSONE, Aija. 2008a. "Tekstilijas Vārkavā". In Vārkava: tradicionālā kultūra un mūsdienas., ed. Janīna Kursīte and Jolanta Stauga. Rīga: Madris, 78-103.

JANSONE, Aija. [2008]b. Dż̄̄ā cimdu un zeķu adī̌sanas tradīcija Vārkavā 20. gadsimta otrajā pusē - 21. gadsimta sākumā. Glove and sock knitting traditions in Vārkava 2nd half of the 20th century - early 21st century. Rìga: Zinātne.

KARLSONE, Anete. 2014. “Atjaunotā tradīcija. Renewed Tradition”. In Rakstainās jostas: kopīgais kultūrslānis. Patterned sashes: the common cultural layer. Rīga: Latvijas Nacionālais kultūras centrs, 62-63, 120-121. 
KIRSHENLATT-GIMBLETT, Barbara. 2004. "Intangible Heritage as Metacultural Production”. Museum, vol. 56/1-2:52-65. https://doi.org/10.1111/j.1350$\underline{0775.2004 .00458 . \mathrm{x}}$

KÖSTLIN, Konrad. 1997. "Feudal Identity and Dogmatized Folk Culture". Journal of Folklore Research, vol. 34/2:105-122. http://www.jstor.org/stable/3814843

KÖSTLIN, Konrad. 1999. "On the Brink of the Next Century: The Necessary Invention of the Present”. Journal of Folklore Research, vol. 36/2-3:289-298. http://www. jstor.org/stable/3814737

"Par 'Satiec savu meistaru!"”. http://www.satiecsavumeistaru.lv/par/ (accessed February 16, 2016).

LNCC archives (without document numbering)

LNCC website, www.satiecsavumeistaru.lv (accessed February 16, 2016)

TSCHOFEN, Bernhard. 1999. "The Habit of Folklore: Remarks on Lived Volkskunde and the Everyday Practice of European Ethnology After the End of Faith". Journal of Folklore Research, vol. 36/2-3:235-242. http://www.jstor.org/stable/3814728

UNESCO: Culture ICH. http://www.unesco.org/culture/ich/en/what-is-intangibleheritage-00003 (accessed February 16, 2016).

UNESCO: Definitions. http://www.unesco.org/culture/ich/en/convention (accessed February 16, 2016).

UNESCO: Baltic song and dance celebrations. http://www.unesco.org/culture/ich/en/RL/ baltic-song-and-dance-celebrations-00087 (accessed February 16, 2016).

UNESCO: Using Natural and Cultural Heritage in Sustainable Development-Synergy for Development. http://whc.unesco.org/en/events/1124 (accessed February 16, 2016).

ZIN̦ĢĪTE, Ilze, ed. 2008. Tautas lietišksā māksla Latvijā : šodiena, pieredze, rītdiena. Rīga: Latvijas Nacionālais vēstures muzejs.

Anete Karlsone

\section{VJEŠTINE TRADICIJSKIH OBRTA U SUVREMENOJ LATVIJSKOJ RURALNOJ SREDINI}

Namjera ovoga rada jest pružiti uvid u ulogu koju vještine tradicijskih obrta zauzimaju u suvremenoj latvijskoj ruralnoj sredini, a kao polazište za promatranje koriste se aktivnosti događanja 'Upoznaj svog majstora!' u organizaciji Latvijskoga nacionalnog centra za kulturu. Zanimanje za tradicijsku kulturnu baštinu, kako društva tako i pojedinaca, potiče 
želja za izražavanjem vlastitoga kulturnog identiteta u današnjem kozmopolitskom svijetu. Ista motivacija potiče uporabu tradicijskih znanja u ruralnom turizmu, aktivnostima pojedinih proizvođača, itd. Tradicijske vještine osnova su uzajamne interakcije među članovima zajednice kao i smislenog provođenja slobodnog vremena, što u cjelini dovodi do poboljšanja kvalitete života.

Ključne riječi: nematerijalna kulturna baština, tradicijske vještine, održivi ruralni razvoj, etnologija

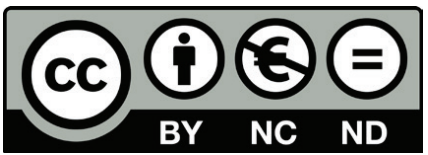

Articles published in this journal are Open Access and can be distributed under the terms and conditions of the Creative Commons license Attribution-NonCommercial-NoDerivatives 4.0 (http://creativecommons.org/licenses/by-nc-nd/4.0/) 